Jurnal Qua Teknika, Vol.6 No.1 Maret 2016

p ISSN: 2088 2424; e ISSN: 2527 3892

UNISBA Blitar, Http://qua.unisbablitar.ejournal.web.id

Ahmad Solihuddin, 2016. Sistem Pengendali Jarak Jauh pada Alat Pengatur Intensitas Cahaya Lampu Pijar.

Jurnal Qua Teknika, (2016), 6(1): 51 68

\title{
SISTEM PENGENDALI JARAK JAUH PADA ALAT PENGATUR INTENSITAS CAHAYA LAMPU PIJAR
}

\author{
Ahmad Solihuddin \\ Jurusan Teknik Elektro, Fakultas Teknik \\ Universitas Muhammadiyah Malang \\ Jl. Tlogomas no 246 Malang
}

\begin{abstract}
Ringkasan
Pada penelitian kali ini membuat alat yang dirancang secara khusus dan merupakan paduan dari beberapa rangkaian elektronika yang terdiri dari rangkaian Catu daya, rangkaian pemancar Inframerah, rangkaian penerima inframerah, rangkaian digital, rangkaian driver relay dan rangkaian dimmer.Dalam pembuatan alat pengendali secara otomatis dilakukan pengaturan intensitas cahaya pada lampu pijar dengan mengendalikan arus yang akan dikendalikan dengan memberikan nilai tahanan tertentu. Pengaturan intensitas cahaya pada lampu pijar ini menggunakan sistem digital dengan kendali jarak jauh (remote control). Bila pada rangkaian dimmer pengaturan dilakukan secara manual dengan merubah nilai tahanan pada potensiometer. Pada perancangan ini tahanan yang diberikan sudah ditentukan dari $470 \mathrm{~K} \Omega$ sampai $56 \mathrm{~K} \Omega$, tiap perubahan tahanan akan merubah terang redup intensitas cahaya pada lampu pijar. Hasil dari kerja alat pengatur intensitas cahaya ini memberikan 10 tahapan nilai tahanan yang mengatur terang redup cahaya lampu pijar dengan cacahan naik, hasil cacahan dapat dilihat pada tampilan tujuh ruas (seven segmen) penunjukkan nilai awal mulai dari angka 0 (nol) sampai 9 (sembilan). Jika dicacah terus maka akan kembali kekondisi awal 0 (nol).
\end{abstract}

Kata kunci: pengendali jara jauh, lampu pijar, intenstas.

\section{PENDAHULUAN}

Teknologi lampu dalam memberikan pencahayaan saat ini telah banyak membantu aktifitas masyarakat dalam melakukan pekerjaannya sehari - hari.. Lampu - lampu yang sering digunakan saat ini adalah lampu neon dan lampu pijar. Pada lampu neon daya yang dikeluarkan kecil tetapi memberikan intensitas yang besar. Sedangkan lampu pijar cahaya yang dihasilkan sesuai dengan daya yang dikeluarkan lampu.. Pembuatan alat ini adalah pengembangan dari rangkaian lampu dimmer yang dapat merubah intensitas cahaya lampu pijar yang dioperasikan secara manual. Pada tugas akhir ini penulis akan merancang alat pengatur intensitas cahaya yang dapat dikendalikan dari jarak jauh. Alat yang dimaksud adalah"Sistem Pengendali Jarak Jauh Pada Alat Pengatur Intensitas Cahaya Lampu Pijar..”Adapun keunggulan dari penggunaan remote kontrol ini adalah pengoperasiannya bisa dilakukan dari jarak jauh dan penggunaannya lebih praktis. Kekurangan dari penggunaan remote kontrol ini perubahan nilai resistansi yang di berikan menggunakan sistem diskrit atau bertahap dan biaya yang mahal. Sedangkan pada rangkaian lampu dimmer keunggulannya selain biaya yang murah lampu dimmer ini memberikan perubahan nilai resistansi diatur dengan sistem kontinyu. 
Adapun yang menjadi tujuan penulisan adalah :Merancang dan membuat alat kendali intensitas cahaya serta mengatur atau merubah besar kecilnya intensitas cahaya untuk lampu pijar dengan kendali jarak jauh (remote control).

\section{METODE}

Dalam perancangan dan realisasi alat pengatur intensitas cahaya ini diharapkan menghasilkan suatu sistem yang dapat mengatur intensitas cahaya pada lampu pijar secara bertahap sesuai dengan tahanan yang diberikan. Perancangan alat pengatur intensitas cahaya ini di realisasikan sesuai dengan komponen yang mudah didapat.

Diagram blok alat pengatur intensitas cahaya pada lampu pijar dapat dilihat pada Gambar 3.1 .

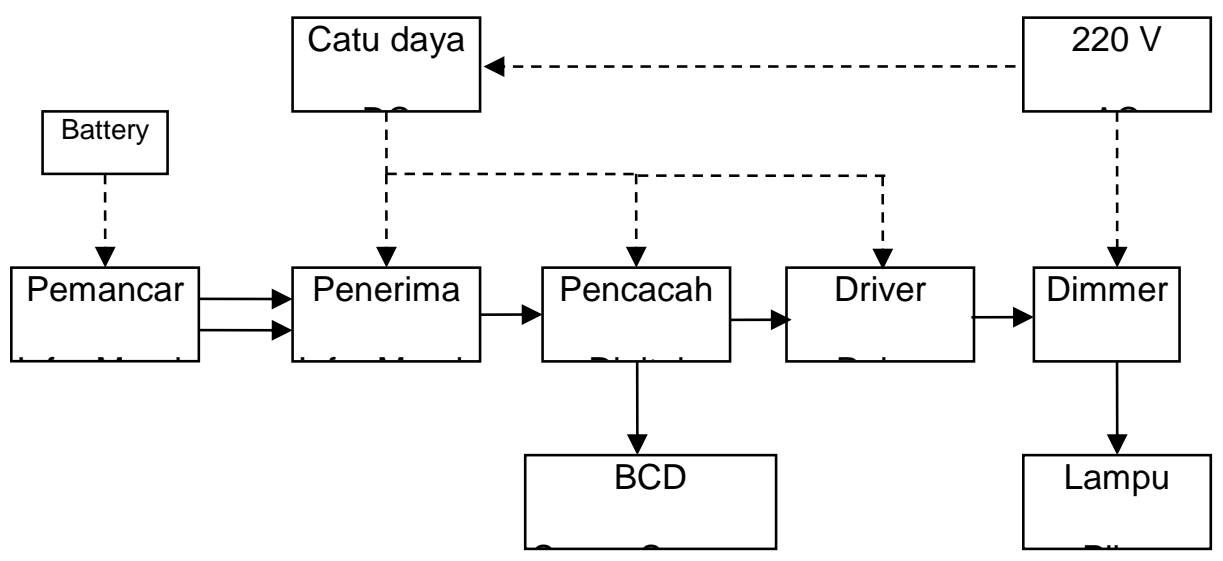

Gambar 3.1 Diagram Blok Rangkaian Pengatur Intensitas Cahaya pada Lampu Pijar

\subsection{Rangkaian Catu Daya}

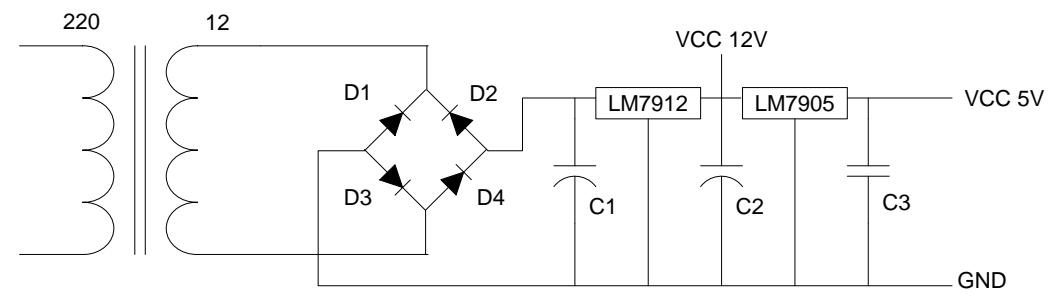

Gambar 3.2. Rancangan Rangkaian Catu Daya

Dalam rangkaian catu daya DC transformator yang digunakan adalah transformator penurun tegangan (Step down Transformator) dengan masukan primer 220 Volt dan keluaran skunder 12 Volt.

Terminal 0 Volt dan 220 Volt pada sisi primer dihubungkan dengan jala - jala PLN. Sedangkan terminal 0 Volt, 5 Volt dan 12 Volt pada sisi skunder dihubungkan kerangkaian penyearah jembatan. Jenis rangkaian penyearah yang digunakan terbangun dari dioda tipe IN 4002. Dioda ini mempunyai kemampuan arus $1 \mathrm{~A}$ dan arus puncak $30 \mathrm{~A}$, sedangkan kemampuan bertahan pada tegangan 50 Volt. 
Untuk menghitung besar arus yang melalui dioda maka tegangan maksimum dari sisi skunder transformator sebagai tegangan masukan pada rangkaian jembatan dapat dihitung dengan persamaan (2.15) sebagai berikut :

$$
\begin{aligned}
& V p=\frac{12}{0,707}=16,97 \text { Volt } \\
& V_{d c}=0,636 \times 16,97=10,79 \text { Volt }
\end{aligned}
$$

Oleh karena arus maksimal yang dapat dialirkan IC regulator LM 7812 sebesar 0,5 A sehingga:

$$
I_{\text {dioda }}=0,5 \times 500 \mathrm{~mA}=250 \mathrm{~mA}
$$

Umumya catu daya DC mempunyai penapis masukan kapasitor yang dirancang dengan riak 10\% atau kurang. Jika tegangan riple yang dikehendaki sebesar 10\% dari tegangan puncak, maka $\quad V_{\text {rip }}=10 \% \times 16,97=1,697$ Volt

$$
\begin{aligned}
& V_{r i p}=\frac{I_{d c}}{2 f . C} \\
& C=\frac{I_{d c}}{2 f \cdot V_{r i p}}=\frac{500 \mathrm{~mA}}{2 \times 50 \times 1,697}=2,946 \times 10^{-3} \\
& C=2946 \times 10^{-6} \mathrm{Farad}
\end{aligned}
$$

Karena nilai kapasitor tidak ada yang bernilai $2946 \mu \mathrm{F}$ maka dalam perancangan akan digunakan kapasitor yang nilainya mendekati yakni $2200 \mu \mathrm{F} / 25 \mathrm{~V}$.Tegangan DC setelah melewati penapis kapasitor hampir mendekati rata, akan tetapi tegangan ini akan terpengaruh dari naik turunnya jala-jala PLN ataupun perubahan beban. Untuk lebih memantapkan lagi tegangan keluaran catu daya DC ini maka digunakan rangkaian integrasi berupa IC regulator positif LM 7812 dan LM 7805. Kapasitor C1 dan C2 pada Gambar 3.2 berfungsi sebagai pengurang riple dari jala-jala listrik bolak-balik. Sedangkan C3 berfungsi untuk memperbaiki tanggapan transien pada tegangan keluaran pada saat beban bertambah.

Komponen yang digunakan adalah.

$$
\begin{array}{ll}
\mathrm{C} 1, \mathrm{C} 2 & =2200 \mu \mathrm{F} / 25 \mathrm{~V} \\
\mathrm{C} 3 & =100 \mathrm{nF} \\
\mathrm{D} 1 . . \mathrm{D} 4 & =\mathrm{IN} 4002 \\
\mathrm{IC} 1, \mathrm{IC} 2 & =\mathrm{LM} 7812, \mathrm{LM} 7805
\end{array}
$$

\subsection{Rangkaian Pemancar Infra Merah}

Rangkaian pemancar sinar infra merah ini berfungsi untuk memancarkan sinar infra merah dalam daerah frekuensi $(38-40 \mathrm{kHz})$. Pada Gambar 3.3 interval frekuensi ini diatur dengan sebuah tahanan variable (VR). 


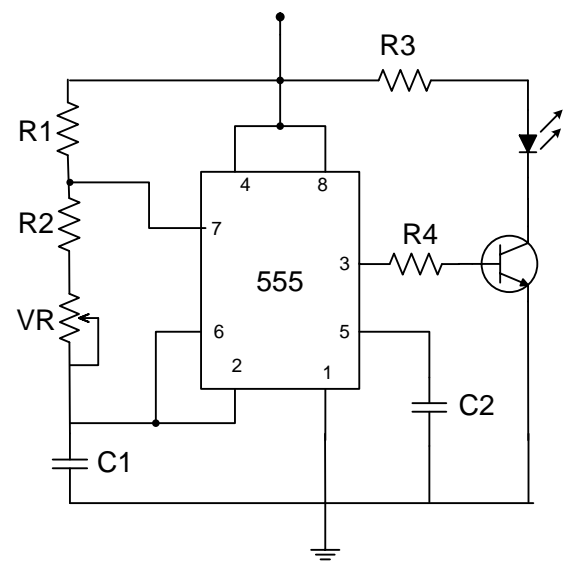

Gambar 3.3. Rangkaian Pemancar Sinar Infra Merah dengan Menggunakan IC NE 555 dalam Operasi Stabil

berdasarkan persamaan (2.6), sehingga didapatkan jumlah total tahanan pengatur lebar frekuensi ini adalah :

$$
\left(R_{1}+2 R_{2}\right)=\frac{1,44}{f \cdot C_{1}}
$$

Untuk menentukan nilai tahanan R2 dan VR digunakan perhitungan melalui persamaan, diasumsikan $\mathrm{C} 1=1 \mathrm{nF}=10^{-9} \mathrm{~F}$, sedangkan jumlah total tahanan $+5 \mathrm{~V}$ maksimum 3,4 $\mathrm{M} \Omega$. Dengan memilih $\mathrm{R} 1=1 \mathrm{k} \Omega$, maka nilai dari tahanan pengatur ini .

$$
V R=\frac{1}{2}\left[\frac{1,44}{f . C}-R_{1}\right]=\frac{1}{2}\left[\frac{1,44}{38 \cdot 10^{3} \times 10^{-9}}-10^{3}\right]=18 \cdot 447,37
$$

Karena nilai tahanan tidak ada yang bernilai $18.447,37=18 \mathrm{~K} \Omega$, maka digunakan VR 20 K $\Omega$.IC NE 555 mempunyai tegangan keluar minimum 2,75 Volt dan maksimum 5Volt saat tinggi untuk catu daya 5Volt, dan 0Volt saat rendah. Doida pemancar sinar infra merah mempunyai jatuh tegangan 2,3 Volt saat menghantar dengan arus $50 \mathrm{~mA}$. Unuk mengamankan IC NE555 dari arus sumber (source) terus menerus sebesar $50 \mathrm{~mA}=50 \times 10^{-3} \mathrm{~A}$ ini, maka dipasang sebuah transistor pada terminal keluaran IC ini seperti ditunjukkan pada Gambar 3.4 dibawah ini:

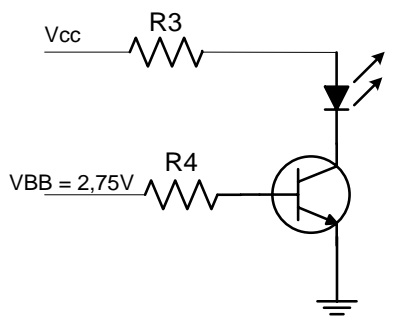

Gambar 3.4. Rangkaian Transistor Switching.

Arus yang dibutuhkan Led IR Gambar 3.4 adalah arus yang melalui R3 dan arus kolektor. Transistor yang dipasang adalah BD 139 dengan arus Kolektor maksimum 1,5A dengan $\beta \mathrm{dc}=$ 
140. Jadi untuk mendapatkan nilai tahanan R3 dan R4 dapat menggunakan persamaan (2.13 dan 2.14) berikut :

$$
R_{3}=\frac{V_{C C}-V_{L E D}}{I c}=\frac{5-2,3}{50 \times 10^{-3}}=54 \Omega
$$

Nilai terdekat untuk R3 adalah $56 \Omega$

$$
I_{B}=\frac{I_{C} m a k s}{\beta d c}=\frac{50 m A}{140}=0,36 m A
$$

Dari nilai - nilai diatas maka harga $\mathrm{R} 4$ didapat :

$$
R_{4}=\frac{V_{B B}-V_{B E}}{I_{B}}=\frac{(2,75-0,7)}{0,36} 5694,44 \Omega=5,694 \mathrm{k} \Omega
$$

Nilai terdekat untuk R4 adalah $5,6 \mathrm{k} \Omega$.

\subsection{Rangkaian Penerima Sinar Infra Merah dan Rangkaian Pewaktu Multivibrator Monostabil}

Rangkaian penerima infra merah menggunakan modul phototransistor yang dihubungkan dengan sumber tegangan, keluaran dari modul phototransistor tranceiver duhubungkan ke input rangkaian pewaktu monostabil.

Rangkaian pewaktu pada perancangan ini dibangun dari IC 555 dengan operasi monostabil yang artinya piranti ini akan stabil pada satu kondisi (tinggi atau rendah) dalam beberapa saat saja.Bila rangkaian penerima Infra merah aktif maka akan memberikan sinyal masukan pada rangkaian monostabil untuk memicu IC 555. Dengan terpicunya IC555 pada pin 2 maka rangkaian pewaktu aktif, untuk selanjutnya akan memicu rangkaian pencacah.Kapasitor harus diisi melalui resistor, semakin besar tetapan waktu $\mathrm{T}=\mathrm{RC}$ maka makin lama tegangan kapasitor untuk mencapai $+2 / 3 \mathrm{Vcc}$, dengan kata lain tetapan waktu RC mengendalikan lebar pulsa keluaran, lamanya pulsa keluaran ini diberikan dalam persamaan:

$$
\begin{aligned}
\mathrm{T} & =\mathrm{R} . \mathrm{C} \\
& =1000000.1 \times 10^{-6}=1 \mathrm{~s}
\end{aligned}
$$

Jadi pada rangkaian ini dapat digunakan tahanan sebesar $1 \mathrm{M} \Omega$ dan Capasitor sebesar $1 \mu \mathrm{F}$.

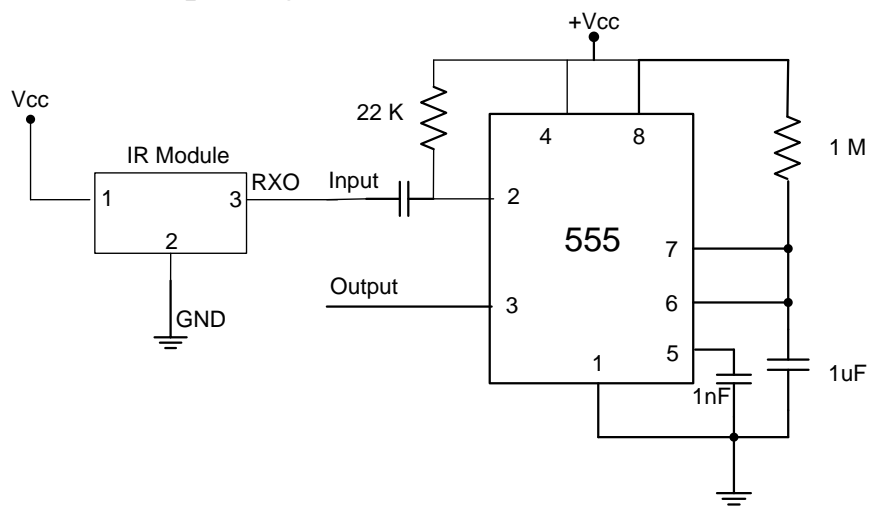

Gambar 3.5. Rangkaian Penerima Inframerah dan Rangkaian Pewaktu Monostabil

\subsection{Rangkaian Pencacah}


Pada rangkaian pencacah ini digunakan IC 74192 yang merupakan IC Up-Down Caunter. IC ini memiliki masukan Up-Down yang terpisah, pada pin 4 untuk menghitung turun dan pada pin 5 untuk menghitung naik.

IC 74192 ini akan menghitung naik apa bila masukan pada pin 5 mendapatkan sinyal masukan rendah (low) sedangkan masukan pin 4 mendapat masukan sinyal tinggi (high). Demikian juga sabaliknya bila menghitung turun, maka masukan pin 4 mendapat sinyal rendah (low) dan masukan naik mendapat sinyal tinggi (high). IC ini tidak bekerja jika pada kedua pin 4 dan 5 mendapat masukan tinggi atau rendah.Keluaran pada IC 74192 ini dihubungkan pada IC 7447, IC ini adalah IC yang akan mengubah hasil cacahan dari bentuk biner ke bentuk desimal, yang akan ditampilkan pada Tampilan Tujuh Ruas (Seven Segmen). Dari tampilan tujuh ruas yang dihubungkan dengan keluaran IC 7447 melalui tahanan $330 \Omega$ berfungsi sebagai pembatas arus pada tampilan tujuh ruas maka akan dapat diketahui nilai/angka penunjukan desimalnya.

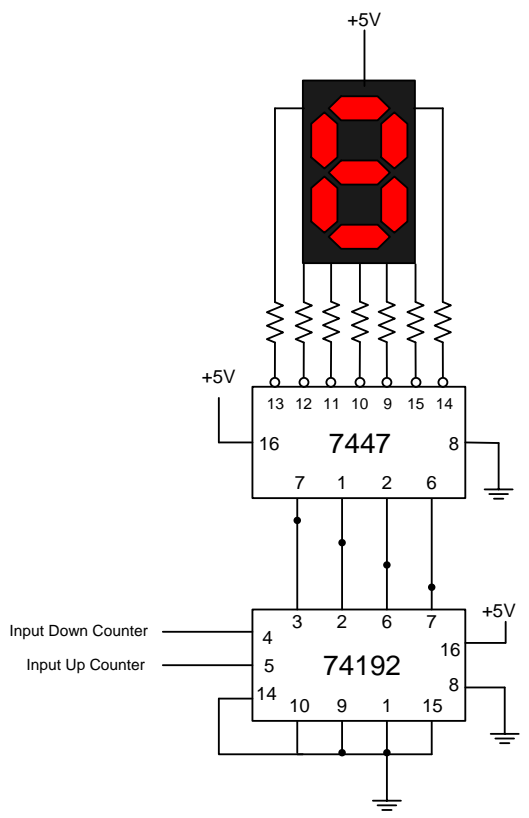

Gambar 3.6. Rangkaian Pencacah dan Tampilan Tujuh Ruas

\subsubsection{Rangkaian Pencacah Ke Dekoder dan Inverter}




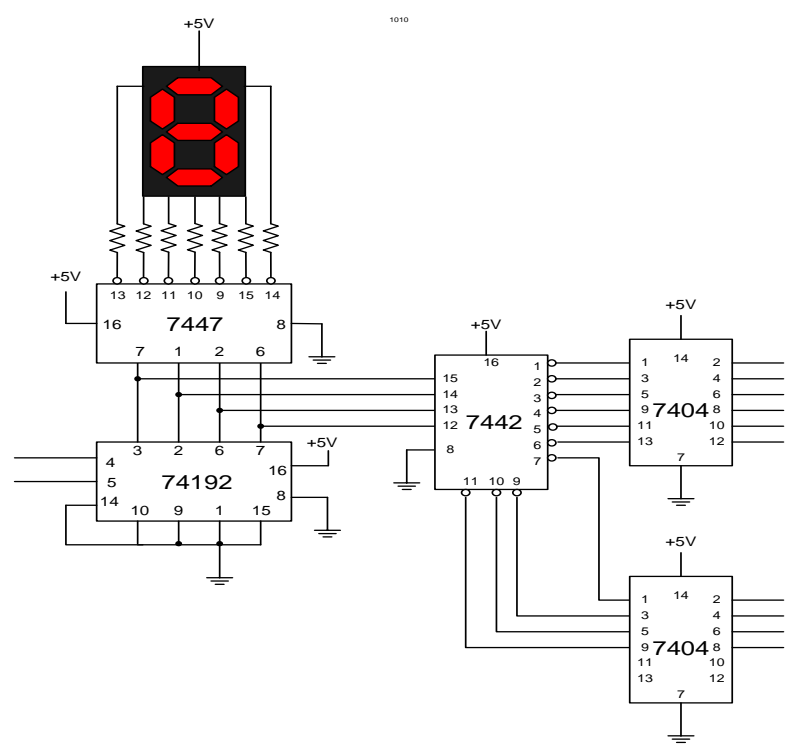

Gambar 3.7. Rangkaian Pencacah 74192, BCD 7447, Tampilan 7 ruas Decoder 7442 dan Inverter 7404

Seperti yang telah dijelaskan cara kerja IC 74192 sebelumnya, keluaran dari IC 74192 tidak hanya di hubungkan ke IC 7447, keluaran IC 74192 juga dihubungkan ke IC dekoder 7442. IC ini berfungsi sebagai pengubah kode biner ke desimal. IC 7442 ini memiliki 4 masukan (Input) dalam bentuk Biner dan 10 keluaran (Output) dalam bentuk desimal. Keluaran dari IC 7442 ini pada kondisi rendah (low). Jadi untuk mendapat kaluaran berupa sinyal tinggi (high), maka pada keluaran IC7442 dihubungkan IC 7404 sebagai inverter.

\subsection{Rangkaian Driver Relay}

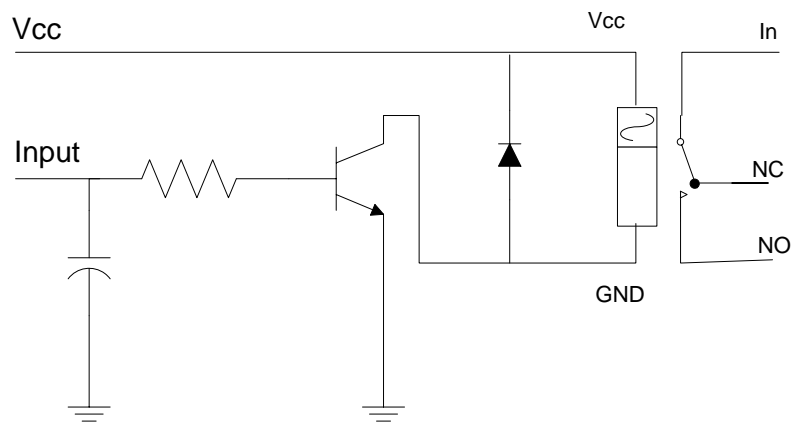

Gambar 3.8. Rangkaian Driver Relay

Rangkaian Driver Relay berfungsi untuk mengendalikan relay mekanik dalam posisi OnOff, yang sesuai dengan perubahan yang diterima rangkaian pencacah, rangkaian menggunakan sebuah transistor BC 547A dan relay DC 12V/ 5 pole dan dioda yang digunakan IN 4002/ IN4004. Tahanan dalam relay jenis ini sebesar $400 \Omega$. Sedangkan transistor switching BC 547A memiliki arus kolektor maksimal sebesar $\mathrm{I}_{\mathrm{c}(\mathrm{mak})}=200 \mathrm{~mA}$ dengan bati penguatan (hfe) sebesar 250. Untuk membuat transistor bekerja sebagai saklar maka basis harus dicatu 
arus atau tegangan. Untuk mendapatkan tahanan basis maka dapat digunakan persamaan (2.12), (2.13) dan (2.14) berikut ini:

$$
\begin{aligned}
& I_{C(s a t)}=\frac{V c c}{R c}=\frac{12}{400}=30 \mathrm{~mA} \\
& I_{b(s a t)}=\frac{I_{c(s a t)}}{h f e}=\frac{30 \mathrm{~mA}}{250}=0,12 \mathrm{~mA} \\
& R_{B}=\frac{V_{B B}-V_{B E}}{I_{b(s a t)}}=\frac{5-0,7}{0,12}=35,833 \Omega
\end{aligned}
$$

Oleh karena tidak ada resistor dengan nilai $35,833 \Omega$ maka dalam perancangan dipakai resistor dengan nilai yang mendekati $39 \mathrm{~K} \Omega$.

\subsection{Rangkaian Dimmer}

Pada rangkaian ini menggunakan Triac BT 137/600 sebagai penyaklaran arus AC. Triac bekerja saat mendapat amplitude denyut pada pin gate. Pegaturan terang redupnya lampu pijar diatur oleh tahanan yang diberikan ke TRIAC. Terang redupnya lampu berdasarkan besar tahanan yang diberikan, semakin besar tahanan yang diberikan maka arus yang mengalir ke lampu menjadi kecil sehingga menyebabkan lampu menjadi redup, demikian sebaliknya jika tahanan yang diberikan kecil maka arus yang mengalir ke lampu menjadi besar sehingga menyebabkan lampu menjadi terang. Gambar rangkaian lampu dimmer dapat dilihat pada Gambar 3.11. Rangkaian lampu dimmer ini merupakan alat yang sudah ada di pasaran.

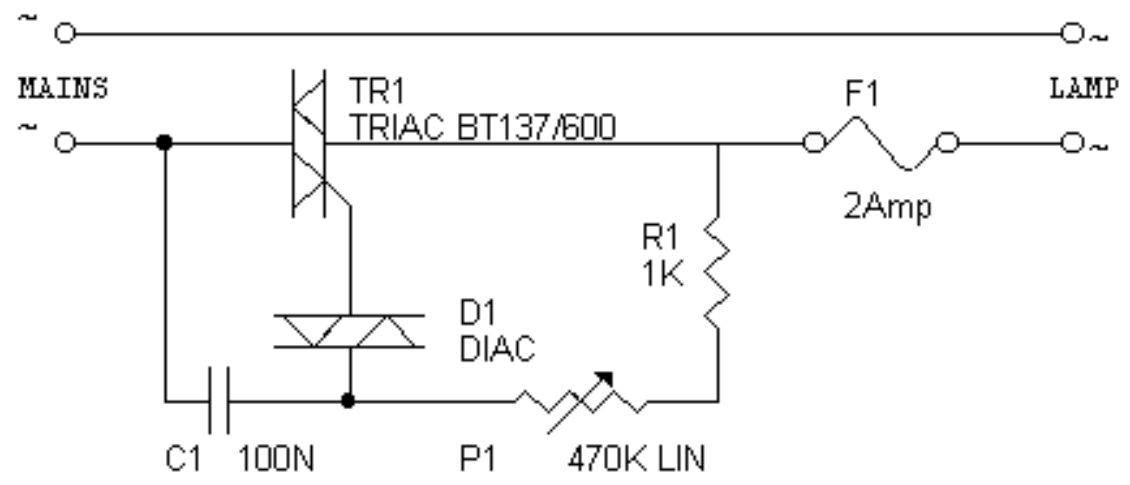

\section{Gambar 3.8. Rangkaian Dimmer}

\section{HASIL DAN ANALISA}

Dalam menganalisa rancangan rangkaian pengatur intensitas cahaya dilakukan dengan menguji dari tiap-tiap unit bagian rangkaian pada pengukuran input dan output rangkaian untuk mendapatkan hasil apakah alat yang dirancang sesuai dengan yang diharapkan. Maka pengujian rangkaian dilakukan sebagai berikut :

1. Pengujian rangkaian Catu Daya

2. Pengujian rangkaian pemancar sinar infra merah

3. Pengujian rangkaian penerima sinar infra merah

4. Pengujian rangkaian pewaktu monostabil

5. Pengujian rangkaian pencacah digital 
6. Pengujian rangkaian driver relay

\subsection{Pengujian rangkaian Catu Daya}

Dalam pengujian rangkaian catu daya dc alat ukur yang digunakan untuk mengukur besaran tegangan digunakan Multimeter digital, ini dilakukan untuk mengetahui apakah rangkaian catu daya dapat menghasilkan tegangan sesuai yang diharapkan, yaitu sebesar $12 \mathrm{~V}$ dan 5V. Pengujian rangkaian catu daya dapat dilihat pada Gambar 4.1 dibawah ini.

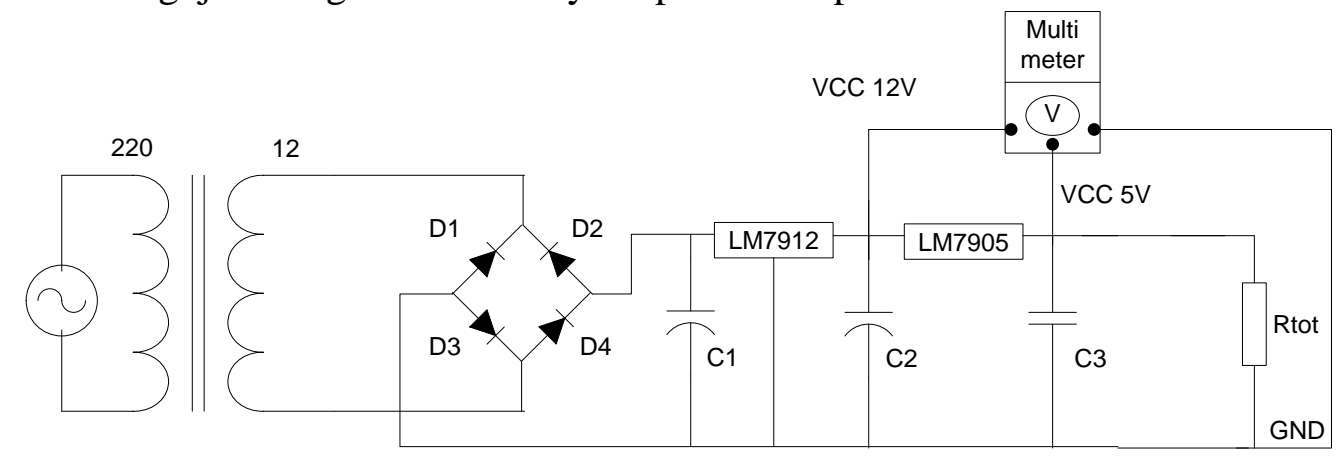

Gambar 4.1 Pengukuran Rangkaian Catu Daya

Dari hasil pengukuran dengan menggunakan multimeter digital didapat nilai tegangan pada IC LM7812 sebesar 12,11Volt dan pada IC LM7805 sebesar 5,02 Volt, Dari hasil pengukuran yang dilakukan dapat dilihat bahwa keluaran IC LM7812 dan IC LM7805 tegangan yang dihasilkan adalah sebesar $12,11 \mathrm{~V}$ dan $5,02 \mathrm{~V}$ yang secara teori seharusnya $12 \mathrm{~V}$ dan $5 \mathrm{~V}$. Selisih nilai ini dapat disebabkan tingkat kepresisian alat ukur yang digunakan yakni $0,1 \%$ dan kurang idealnya nilai tegangan dirangkaian yang dipengaruhi tahanan dalam alar ukur yang bertindak sebagai beban tambahan yang di dalam perhitungan tidak merupakan variabel yang dihitung.

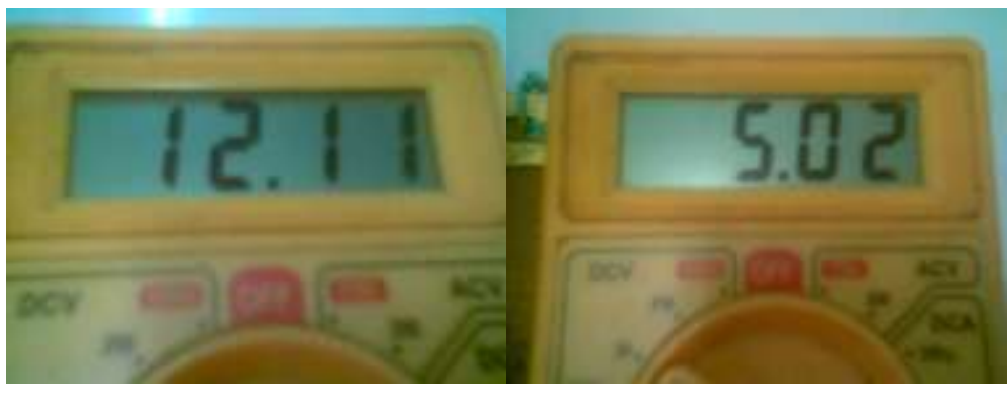

Gambar 4.2. Hasil Pengukuran Multimeter (Digital)

\subsection{Pengujian Rangkaian Pemancar Infra Merah}

Rangkaian pengujian pemancar Infra merah dapat dilihat pada Gambar 4.3 di bawah ini. 


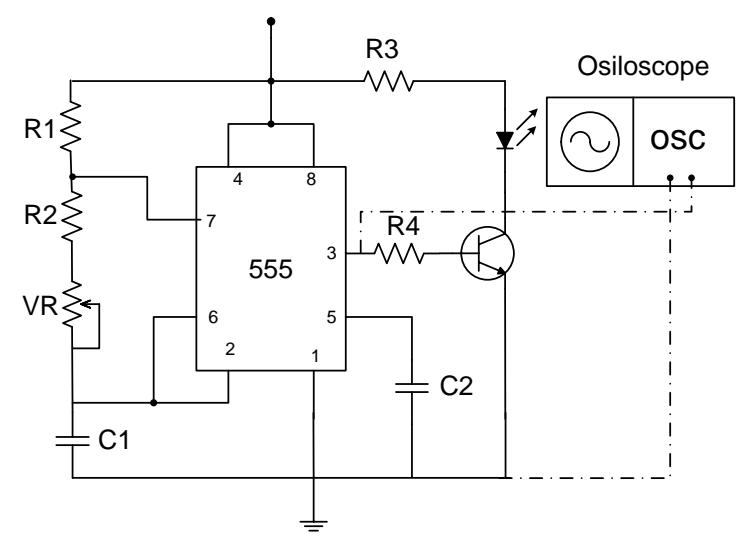

Gambar 4.3. Pengujian Rangkaian Pemancar Infra Merah

Pengujian ini dilakukan adalah untuk mengukur frekuensi gelombang keluaran dari IC 555. alat ukur yang digunakan dalam pengujian ini adalah Oscilloscope. Pada pengujian ini didapatkan hasil pengukuran sebesar $40 \mathrm{KHz}$, didapat dari persamaan sebagai berikut :

Time/Div $=10 \mu \mathrm{s}$

$\operatorname{Perioda}(\mathrm{T})=2,5 \mathrm{div}$

Sehingga frekuensinya :

$$
f=\frac{1}{T}=\frac{1}{2,5 \times 10.10^{-6}}=\frac{1}{25} \times 10^{6}=40.000 \mathrm{~Hz}=40 \mathrm{KHz}
$$

Dalam hasil perhitungan dengan menggunakan persamaan (2.6), untuk nilai komponen $\mathrm{C}_{1}$ $=1 \mathrm{nF}, \mathrm{R}_{1}=1 \mathrm{~K} \Omega$, nilai frekuensi telah ditentukan $38 \mathrm{Khz}-40 \mathrm{KHz}$, jadi dalam perhitungan hanya mencari nilai VR. yaitu sebesar $20 \mathrm{~K} \Omega$. Gambar hasil pengujian pada oscilloscope dapat dilihat pada Gambar 4.4 dibawah ini.

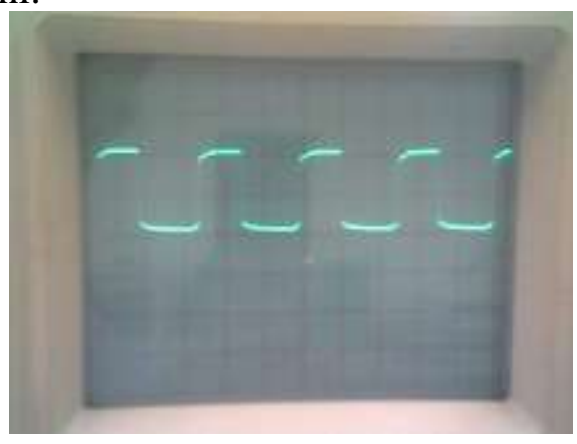

Gambar 4.4. Hasil Pengujian Rangkaian Pemancar Infra Merah

\subsection{Pengujian Rangkaian Penerima Infra Merah}

Pengujian rangkaian penerima infra merah ini dapat dilihat pada Gambar 4.3. di bawah ini. 


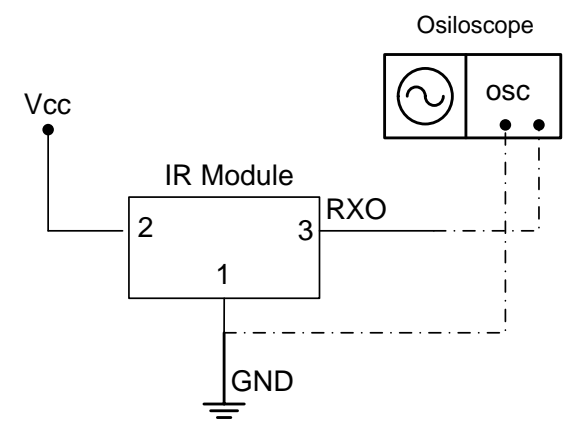

Gambar 4.5. Pengujian Penerima Infra Merah

Pada pengujian ini menggunakan alat ukur Oscilloscope untuk melihat unjuk kerja dari phototransistor saat mendapat sinyal masukan dari pemancar sinar infra merah. Hasil pengujian pada oscilloscope menunjukkan saat phototransistor mendapat masukkan sesaat dari pemancar infra merah, keluaran dari RXO menjadi tinggi (high), dan kembali kekondisi awal saat tidak mendapat sinyal input dari pemancar infra merah. Kondisi ini akan terus menerus selama mendapat masukan sesaat dari pemancar infra merah. Hasil pengujiannya dapat dilihat pada Gambar 4.6 dibawah ini.

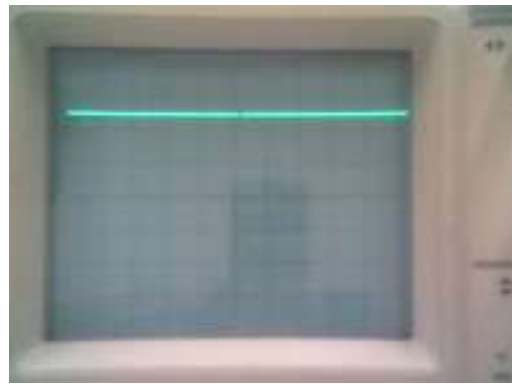

(a)

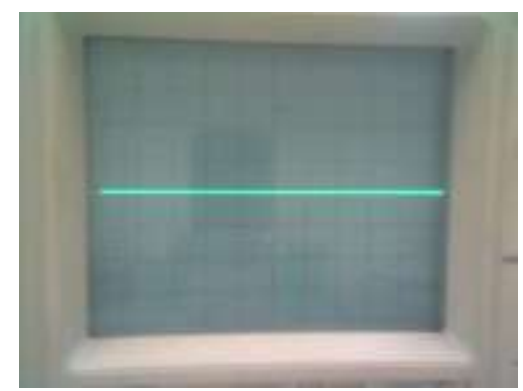

(b)

Gambar 4.6. Hasil Pengujian Output dari Rangkaian Penerima Infra Merah

(a). Tampilan Oscilloscope Saat input dalam keadaan Rendah (Low)

(b). Tampilan Oscilloscope saat input dalam keadaan Tinggi (High)

\subsection{Pengujian Rangkaian Pewaktu Monostabil}

Pengujian rangkaian pewaktu monostabil dapat dilihat pada Gambar 4.7 dibawah ini :

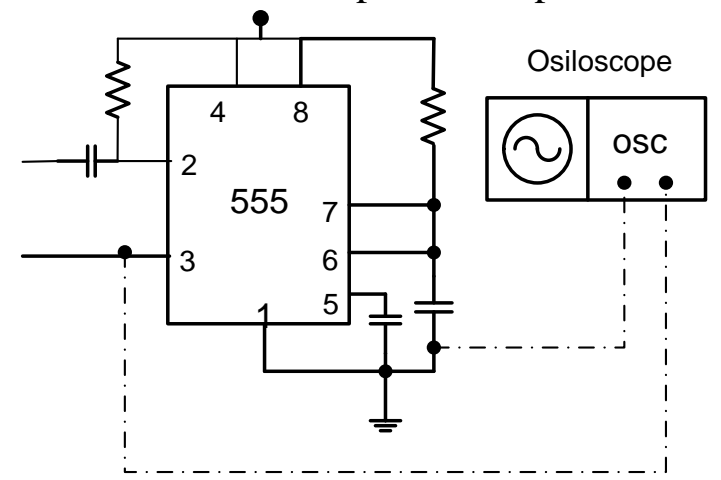

Gambar 4.7. Pangujian Rangkaian Pewaktu 
Pengujian ini menggunakan alat ukur Oscilloscope untuk melihat unjuk kerja dari rangkaian pewaktu, sinyal masukan pada pin 2 diterima dari keluaran rangkaian penerima infra merah, saat mendapat masukan sinyal keluaran pada pin 3 hanya sesaat dan kembali ke kondisi awal. Saat mendapat input rendah (Low) keluran dari rangkaian pewaktu monostabil akan terpicu tinggi (High). Begitu sebaliknya saat mendapat input tinggi (High) maka keluaran dari rangkaian pewaktu monostabil akan terpicu rendah (Low). Dari hasil pengujian ini dapat disimpulkan bahwa rangkaian pewaktu yang dirancang dapat digunakan untuk memberikan masukan pada rangkaian pencacah yang bekerja pada kondisi rendah (Low). Sehingga pencacah akan aktif.

\subsection{Pengujian Rangkaian Pencacah Digital}

\subsubsection{Pengujian Pencacah Up/Down Counter IC 74192}

Pengujian pencacah naik (up) dan turun (down) bertujuan untuk mengetahui bagaimana pencacah dapat melakukan perhitungan naik dan turun, dan membuktikan bahwa rangkaian yang dibuat sesuai dengan perancangan. Pengujian dilakukan dengan menggunakan penyidik logika (logic probe) dan dua buah saklar. Pengujian Pencacah dapat dilihat pada Gambar 4.8 dibawah ini.

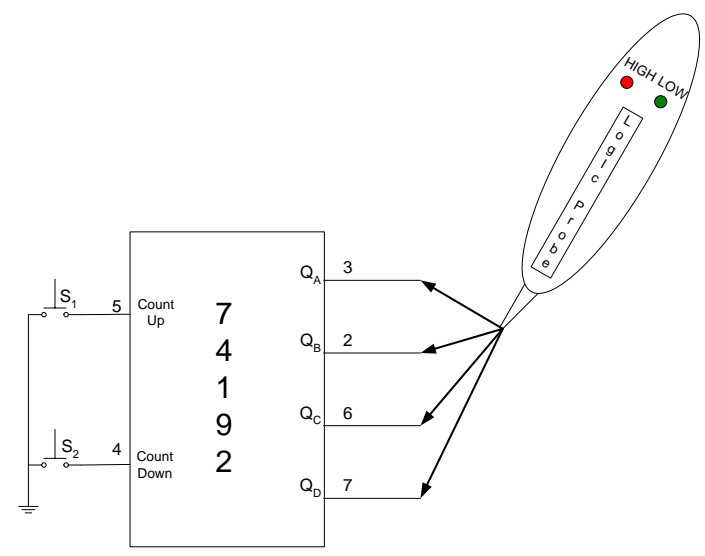

Gambar 4.8 Pengujian Pencacah Up/Down Counter IC 74192

\subsubsection{Pencacah Naik}

IC pencacah (74192) pada pin 5 (count up) diberi tegangan rendah (0 volt) dengan menggunakan saklar 1, sedangkan pin 4 (count down) tetap diberi tegangan tinggi (5 volt). Kemudian dengan menekan saklar 1 secara berulang-ulang sebanyak sembilan kali, maka keluaran pin $3(\mathrm{QA})$, pin 2 (QB), pin 6 (QC), dan pin 7 (QD) dapat dilihat pada Tabel 4.1 berikut.

Tabel 4.1 Hasil Pengujian Pencacah Naik

\begin{tabular}{|c|c|c|c|c|c|}
\hline $\begin{array}{c}\text { Tekan Saklar } \\
1 \mathrm{ke}\end{array}$ & QAPin 3 & QBPin 2 & QCPin 6 & QDPin 7 & Desimal \\
\hline 0 & 0 & 0 & 0 & 0 & 0 \\
\hline 1 & 0 & 0 & 0 & 1 & 1 \\
\hline
\end{tabular}




\begin{tabular}{|l|l|l|l|l|l|}
\hline 2 & 0 & 0 & 1 & 0 & 2 \\
\hline 3 & 0 & 0 & 1 & 1 & 3 \\
\hline 4 & 0 & 1 & 0 & 0 & 4 \\
\hline 5 & 0 & 1 & 0 & 1 & 5 \\
\hline 6 & 0 & 1 & 1 & 0 & 6 \\
\hline 7 & 0 & 1 & 1 & 1 & 7 \\
\hline 8 & 1 & 0 & 0 & 0 & 8 \\
\hline 9 & 1 & 0 & 0 & 1 & 9 \\
\hline
\end{tabular}

\subsubsection{Pencacah turun}

IC pencacah (74192) pada pin 4 (count down) diberi tegangan rendah (0 volt) dengan menggunakan saklar 2, sedangkan pin 5 (count up) tetap diberi tegangan tinggi (5 volt). Kemudian dengan menekan saklar 2 secara berulang-ulang sebanyak sembilan kali, maka keluaran pin 3 (QA), pin 2 (QB), pin 6 (QC), dan pin 7 (QD) dapat dilihat pada Tabel 4.2 berikut :

Tabel 4.2 Hasil Pengujian Pencacah Turun

\begin{tabular}{|c|c|c|c|c|c|}
\hline $\begin{array}{c}\text { Tekan Saklar } \\
1 \mathrm{ke}\end{array}$ & QAPin 3 & QBPin 2 & QCPin 6 & QDPin 7 & Desimal \\
\hline 0 & 1 & 0 & 0 & 1 & 9 \\
\hline 1 & 1 & 0 & 0 & 0 & 8 \\
\hline 2 & 0 & 1 & 1 & 1 & 7 \\
\hline 3 & 0 & 1 & 1 & 0 & 6 \\
\hline 4 & 0 & 1 & 0 & 1 & 5 \\
\hline 5 & 0 & 1 & 0 & 0 & 4 \\
\hline 6 & 0 & 0 & 1 & 1 & 3 \\
\hline 7 & 0 & 0 & 1 & 0 & 2 \\
\hline 8 & 0 & 0 & 0 & 1 & 1 \\
\hline 9 & 0 & 0 & 0 & 0 & 0 \\
\hline
\end{tabular}

Dari Tabel 4.1 dan 4.2 di atas dapat disimpulkan bahwa jika pin 5 diberikan logika 0 maka pencacah akan menghitung naik, sedangkan jika pin 4 yang diberikan logika 0 maka pencacah akan menghitung turun.

\subsubsection{Pengujian IC Dekoder 7447}



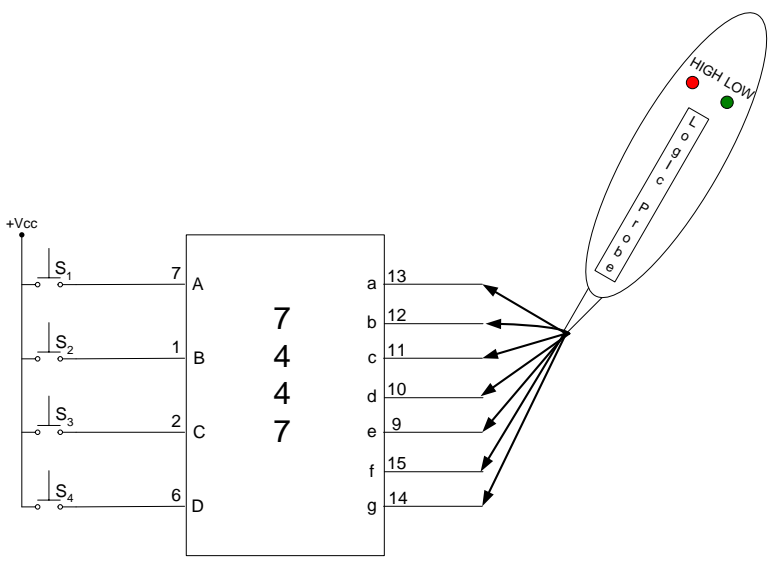

Gambar 4.9. Pengujian IC Dekoder 7447

Pengujian IC dekoder 7447 bertujuan untuk mengetahui tidak terjadi kesalahan pembacaan pada tampilan tujuh ruas. Pengujian dilakukan dengan menggunakan penyidik logika (logic probe) dan empat buah saklar. Seperti terlihat pada Gambar 4.9.

Dengan menghubungkan saklar S1, S2, S3, dan S4 dengan tegangan Vcc. Tekan saklar sesuai dengan Tabel 4.8, maka kondisi keluaran dari pin $a(13), b(12), c(11), d(10), e(9), f$ (15), dan $g$ (14) dapat dilihat Tabel 4.3 berikut:

Tabel 4.3. Hasil Pengujian Dekoder 7447

\begin{tabular}{|c|c|c|c|c|c|c|c|c|c|c|c|}
\hline \multicolumn{4}{|c|}{ Masukan } & \multicolumn{9}{|c|}{ Keluaran } & Desimal \\
\hline S4 & S3 & S2 & S1 & $\boldsymbol{A}$ & $\boldsymbol{B}$ & $\boldsymbol{c}$ & $\boldsymbol{d}$ & $\boldsymbol{E}$ & $\boldsymbol{F}$ & $\boldsymbol{g}$ & \\
\hline 0 & 0 & 0 & 0 & 0 & 0 & 0 & 0 & 0 & 0 & 1 & 0 \\
\hline 0 & 0 & 0 & 1 & 1 & 0 & 0 & 1 & 1 & 1 & 1 & 1 \\
\hline 0 & 0 & 1 & 0 & 0 & 0 & 1 & 0 & 0 & 1 & 0 & 2 \\
\hline 0 & 0 & 1 & 1 & 0 & 0 & 0 & 0 & 1 & 1 & 0 & 3 \\
\hline 0 & 1 & 0 & 0 & 1 & 0 & 0 & 1 & 1 & 0 & 0 & 4 \\
\hline 0 & 1 & 0 & 1 & 0 & 1 & 0 & 0 & 1 & 0 & 0 & 5 \\
\hline 0 & 1 & 1 & 0 & 1 & 1 & 0 & 0 & 0 & 0 & 0 & 6 \\
\hline 0 & 1 & 1 & 1 & 0 & 0 & 0 & 1 & 1 & 1 & 1 & 7 \\
\hline 1 & 0 & 0 & 0 & 0 & 0 & 0 & 0 & 0 & 0 & 0 & 8 \\
\hline 1 & 0 & 0 & 1 & 0 & 0 & 0 & 1 & 1 & 0 & 0 & 9 \\
\hline
\end{tabular}

Dari hasil pengujian dapat dilihat bahwa dengan memberikan masukan pada A, B, C, dan $\mathrm{D}$ akan menghasilkan suatu bentuk keluaran angka tertentu. Apabila masukan yang diberikan pada kondisi 0000 maka keluaran dekoder akan menampilkan angka 0 pada peraga tujuh ruas. Demikian juga bila masukan yang diberikan pada kondisi 1001 maka keluaran dekoder akan menampilkan angka 9 pada peraga tujuh ruas.

\subsubsection{Pengujian IC Decoder 7442}

Pengujian ini bertujuan untuk mengetahui hasil keluaran dari IC Decoder 7442, apakah sesuai dengan yang diharapkan. Pengujian dilakukan dengan menggunakan penyidik logika 
(logic probe) dan empat buah saklar. Pengujian ini hampir sama dengan pengujian pada IC Decoder 7447 menggunaan 4 masukan, hanya saja pada IC Decoder 7442 ini memiliki 10 keluaran. Seperti yang terlihat pada Gambar 4.10 dibawah ini.

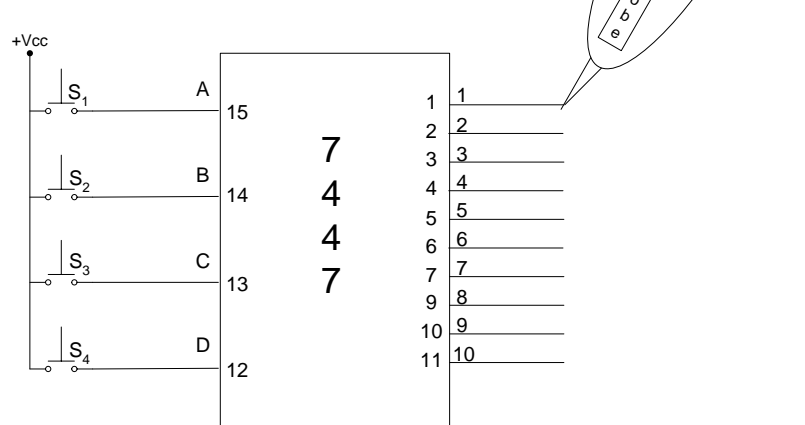

Gambar 4.10 Pengujian IC Decoder 7442

Dengan menghubungkan saklar $\mathrm{S}_{1}, \mathrm{~S}_{2}, \mathrm{~S}_{3}$ dan $\mathrm{S}_{4}$ dengan tegangan Vcc, tekan saklar sesuai dengan Tabel 4.4, maka kondisi pin 1 sampai pin 10 dapat dilihat pada Tabel berikut.

Tabel 4.4. Tabel Pengujian IC Decoder 7442

\begin{tabular}{|c|c|c|c|c|c|c|c|c|c|c|c|c|c|c|}
\hline \multirow{2}{*}{$\begin{array}{c}\text { PIN } \\
\text { ke }\end{array}$} & \multicolumn{4}{|c|}{ Masukan } & \multicolumn{10}{|c|}{ Keluaran } \\
\hline & D & $\mathbf{C}$ & B & $\mathbf{A}$ & $\mathbf{0}$ & 1 & 2 & 3 & 4 & 5 & 6 & 7 & 8 & 9 \\
\hline 1 & 0 & 0 & 0 & 0 & $\mathbf{0}$ & 1 & 1 & 1 & 1 & 1 & 1 & 1 & 1 & 1 \\
\hline 2 & 0 & 0 & 0 & 1 & 1 & $\mathbf{0}$ & 1 & 1 & 1 & 1 & 1 & 1 & 1 & 1 \\
\hline 3 & 0 & 0 & 1 & 0 & 1 & 1 & $\mathbf{0}$ & 1 & 1 & 1 & 1 & 1 & 1 & 1 \\
\hline 4 & 0 & 0 & 1 & 1 & 1 & 1 & 1 & 0 & 1 & 1 & 1 & 1 & 1 & 1 \\
\hline 5 & 0 & 1 & 0 & 0 & 1 & 1 & 1 & 1 & $\mathbf{0}$ & 1 & 1 & 1 & 1 & 1 \\
\hline 6 & 0 & 1 & 0 & 1 & 1 & 1 & 1 & 1 & 1 & $\mathbf{0}$ & 1 & 1 & 1 & 1 \\
\hline 7 & 0 & 1 & 1 & 0 & 1 & 1 & 1 & 1 & 1 & 1 & $\mathbf{0}$ & 1 & 1 & 1 \\
\hline 9 & 0 & 1 & 1 & 1 & 1 & 1 & 1 & 1 & 1 & 1 & 1 & $\mathbf{0}$ & 1 & 1 \\
\hline 10 & 1 & 0 & 0 & 0 & 1 & 1 & 1 & 1 & 1 & 1 & 1 & 1 & 0 & 1 \\
\hline 11 & 1 & 0 & 0 & 1 & 1 & 1 & 1 & 1 & 1 & 1 & 1 & 1 & 1 & 0 \\
\hline
\end{tabular}


Dari hasil pengujian dapat dilihat bahwa dengan memberikan masukan pada A, B, C, dan $\mathrm{D}$ akan menghasilkan suatu bentuk keluaran berlogika 0 dan 1 . Apabila masukan yang diberikan pada kondisi 0000 maka keluaran dekoder pada pin 1 akan berlogika 0 , dan pada pin yang lainnya akan berlogika 1, jika pada masukan diberi masukan pada kondisi 0001 maka pada keluaran decoder pin 2 akan berlogika 0 , dan pada pin yang lainnya berlogika 1 . Demikian juga bila masukan yang diberikan pada kondisi 1001 maka pada keluaran pin 11 akan berlogika 0 , dan pin lainnya berlogika 1 .

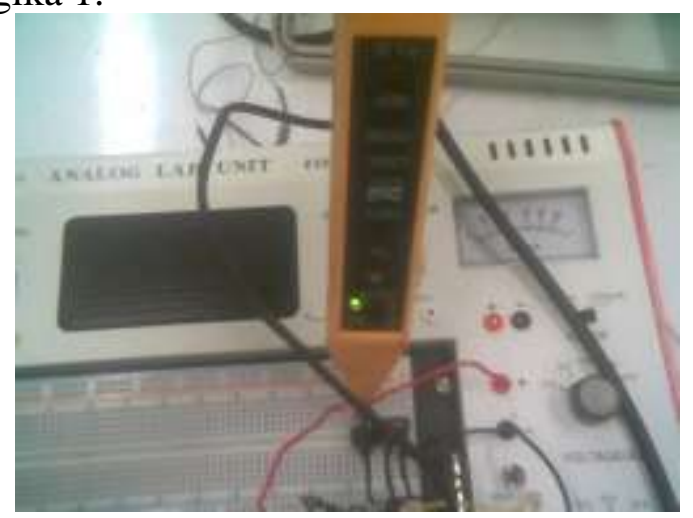

Gambar 4.11. Pengujian IC Dengan Penyidik Logika (Logic Probe)

\subsection{Pengujian Rangkaian Driver Relay}

Pengujian Driver Relay dapat dilihat pada Gambar 4.10 dibawah ini.

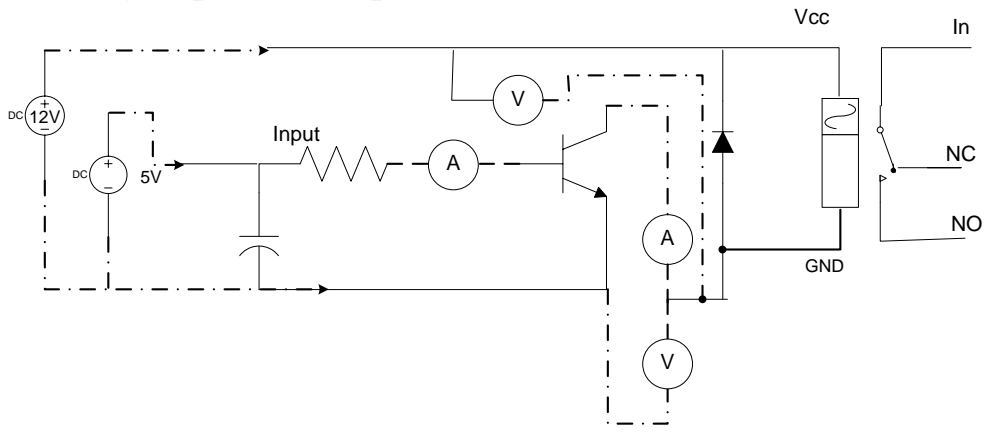

Gambar 4.12 Pengujian Rangkaian Driver Relay

Pengujian ini menggunakan sumber tegangan DC 12 Volt dan 5 Volt, ini dilakukan untuk melihat apakah relay yang akan digunakan berkerja dengan baik. Tegangan 12 Volt diberikan pada sumber tegangan relay dan tegangan 5 Volt diberikan pada input. Saat input diberikan tegangan maka akan mengalirkan arus ke Transistor yang menyebabkan transistor bekerja seperti saklar yang menghubungkan kaki kolektor ke emitor, ini membuat kaki grond relay terhubung ke Ground, Sehingga relay bekerja dengan baik.Dari percobaan yang telah dilakukan sesuai dengan Gambar rangkaian pemicu diatas didapat hasil pengukuran sebagai berikut :

Tabel 4.5. Hasil Pengukuran Rangkaian Driver Relay

\begin{tabular}{|l|l|l|l|}
\hline$V_{\text {in }}$ & Hasil Pengukuran & Hasil Perhitungan & Relay \\
\hline
\end{tabular}


Jurnal Qua Teknika, Vol.6 No.1 Maret 2016

p ISSN: 2088 2424; e ISSN: 2527 3892

UNISBA Blitar, Http://qua.unisbablitar.ejournal.web.id

Ahmad Solihuddin, 2016. Sistem Pengendali Jarak Jauh pada Alat Pengatur Intensitas Cahaya Lampu Pijar.

Jurnal Qua Teknika, (2016), 6(1): 51 68

\begin{tabular}{|c|c|c|c|c|c|c|c|}
\hline & $\begin{array}{c}\mathbf{A}_{1} \\
(\mathbf{m A})\end{array}$ & $\mathbf{A}_{2}(\mathbf{m a})$ & $\mathbf{V}_{\mathbf{1}}(\mathbf{V})$ & $\mathbf{V}_{\mathbf{2}}(\mathbf{V})$ & $\mathbf{A}_{\mathbf{1}}(\mathbf{m A})$ & $\mathbf{A}_{2}(\mathbf{m a})$ & \\
\hline 0 & 0 & 0 & 0 & 12,11 & 0 & 0 & OFF \\
\hline 5,02 & 0,11 & 27,55 & 11,04 & 1,48 & 0,1107 & 27,675 & ON \\
\hline
\end{tabular}

Secara perhitungan besar $\mathrm{I}_{\mathrm{b}}\left(\mathrm{A}_{1}\right)$ dan $\mathrm{I}_{\mathrm{c}}\left(\mathrm{A}_{2}\right)$ pada rangkaian percobaan dapat dihitung berdasarkan persamaan (2.13) dan (2.14) sebagai berikut:

$$
\begin{aligned}
& I_{b}=\frac{V_{\text {in }}-V_{b e}}{R_{b}} \\
& I_{C}=I_{b} \cdot h f e
\end{aligned}
$$

Untuk rangkaian percobaan pemicu 2 ampere, nilai tahanan dalam relay adalah $400 \Omega$, $h f e$ transistor BC 547A adalah sebesar 259. sedangkan $V_{\text {in }}$ sebesar 5,02 Volt dan tahanan basis $39 \mathrm{~K} \Omega$

$$
\begin{aligned}
& A_{1}=\frac{5,02-0,7}{39000}=\frac{4,32 \mathrm{~V}}{39000}=\frac{4320}{39000}=0,1107 \mathrm{~mA} \\
& A_{2}=0,1107 \times 250=27,675 \mathrm{~mA}
\end{aligned}
$$

Bila dilihat hasil pengukuran dan hasil perhitungan, besar nilai $\mathrm{I}_{\mathrm{b}}$ dan $\mathrm{I}_{\mathrm{c}}$ tidak mengalami perbedaan yang besar, tetapi perbedaan pada nilai $\mathrm{I}_{\mathrm{c}}$ antara hasil pengukuran dan perhitungan disebabkan oleh perbedaan nilai $I_{b}$ yang didapat secara perhitungan dan pengukuran. Karena yang menentukan besar kecilnya arus yang lewat dikolektor transistor ditentukan oleh besar arus yang masuk ke basis transistor dikali dengan besar $h f e$ dari transistor.

\section{KESIMPULAN DAN SARAN}

Dari hasil perancangan, pengamatan dan pengujian alat pengatur intensitas cahaya untuk lampu pijar, maka dapat diambil kesimpulan sebagai berikut: 1) Dari hasil pengamatan dan pengujian terlihat setiap rangkaian bekerja dengan baik sesuai dengan yang dirancang. 2) Pengaturan Intensitas cahaya pada perancangan alat ini hanya mempunyai 10 (sepuluh) tahapan. Ini disebabkan karena pada rangkaian digital hanya memiliki 10 keluaran yang akan memicu Driver Relay. 3) Jarak antara rangkaian pemancar inframerah dan penerima inframerah ditentukan dari besar frekuensi yang diberikan. Untuk jarak yang jauh digunakan frekuensi $38 \mathrm{KHz}-40 \mathrm{KHz}$. 4) Modul Penerima inframerah merupakan variabel yang sangat berpengaruh terhadap unjuk kerja alat yang dirancang, karena modul ini memiliki sensitivitas yang tinggi.

Diharapkan untuk penelitian berikutnya dalam pembuatan alat lebih ditekankan pada akurasi sensor pada alat tersebut sebab dalam pemakaian kedepan dibutuhkan alat yang lebih kompatibel dan multi fungsi. Jarak yang dipakai dalam kendali diharapkan lebih semakin jauh dan luas cakupan lebih memadai.

\section{DAFTAR PUSTAKA}

Albert Paul Malvino. Prinsip - prinsip Elektronika Jilid 1. Penerbit Erlangga, 1995 
Delton T.Horn. Teknik Merancang Dengan Transistor. penerbit PT Elex Media Komputindo, Kelompok Gramedia, Jakarta 1988.

Erwin Suryadi. Perancangan Alat Kendali Temperratur Pada Overhead Projector, Skripsi Fakultas Teknik Universitas Tanjungpura Pontianak 2004.

Gatot Soedarto. Dasar - dasar Sistem Digital, Penerbit Usaha Nasional. Surabaya.

H.Ritz. Teknik Digit 1 Kursus Dasar Elektronika Digit, penerbit PT Elex Media Komputindo, Kelompok Gramedia, Jakarta 1987.

Jamhir Islami. Perancangan Tempat Parkir Khusus Untuk Kendaraan Roda Empat Berdasarkan Jumlah Kendaraan Dengan Menggunakan Programmable Logic Controller (PLC Simatic S5-95U). Skripsi Fakultas Teknik Universitas Tanjungpura Pontianak 2005.

Jannus Marpaung. Perancangan dan Realisasi Sistem Pengaturan Pintu Otomatis Dengan Menggunakan Sensor Infra Merah. Skripsi Fakultas Teknik Universitas Tanjungpura Pontianak 1996.

KF. Ibrahim. Teknik Digital, Penerbit ANDI Yogyakarta

Lantip Tri Wibowo. Perancangan Saklar Otomatis Penerangan Berbasis Jumlah Orang, Skripsi Fakultas Teknik Universitas Tanjungpura Pontianak 2002.

Roger L. Tokheim. Elektronika Digital Edisi Kedua, Penerbit Erlangga.

Rufus. P. Turner \& Brinton L. Rutherford. 133 Rangkaian Elektronika, Penerbit PT Elex Media Komputindo Kelompok Gramedia, Jakarta 1993.Wasito S., 1986, Vedemekum 